\title{
UVODNIK GOSTUJOČE UREDNICE
}

Uvodne misli si bom drznila začiniti z nekaj humorja. Še pred dobrimi sto leti v avstro-ogrski vojski ni bilo zaželeno, da se mladi častniki prekmalu poročijo in ustvarijo družino. Njihove misli so morale ostati bistre in njihovo srce na pravi strani, pri državi in ne dekletu. Slovenski vojak in vojakinja sta danes zato lahko zadovoljna, da se smeta poročiti in imeti družino. Naj bo to bežen in humoren zgodovinski komentar, ki se dotika tudi vsebin, ki so natančneje in resneje opisane na naslednjih straneh te posebne številke.

Vojaške družine so že vsaj 50 let pomembna tema različnih znanosti po svetu, v Sloveniji pa orjemo ledino tako s popisom dosedanjih spoznanj kot tudi s celovitim pristopom k preučevanju vojaških družin. Fakulteta za družbene vede Univerze v Ljubljani s sodelovanjem Mirovnega inštituta od julija 2019 izvaja projekt Vojaško specifični dejavniki tveganja za dobrobit in zdravje vojaških družin ob podpori Javne agencije za raziskovalno dejavnost Republike Slovenije. Raziskovalci smo zelo hvaležni, ker nas pri raziskovalnih prizadevanjih organizacijsko podpira Slovenska vojska in ker je bilo uredništvo revije Sodobni vojaški izzivi pripravljeno podpreti naše delo tako, da je namenilo celotno številko tej pomembni temi, ki pa, to moramo priznati, z vidika vojske predstavlja podporno dejavnost, vendar ob vseh drugih izzivih morda obrobno tematiko. Vemo pa tudi, da je za vsak boj podpora zelo pomembna in morda lahko pomembno pripomore $\mathrm{k}$ zmagi.

V uvodu naj opredelim predmet preučevanja te številke revije. Družino umeščamo v civilno okolje. Kam pa umeščamo in kako razumemo vojaško družino? V Sloveniji ni vojaških baz, v katerih bi bile družine podvržene vojaški socializaciji, ni prepletanja vojaške hirerhije z družbenim položajem družine. V državi blaginje, za kakršno imamo Slovenijo, vojaškim družinam niso ponujene posebne ugodnosti, ki bi jih v civilnem okolju ločevale od drugih. V ZDA, na primer, so vojaške družine velikokrat 
fizično ločene od civilnega okolja in podrejene vojaškim zahtevam, v Estoniji se termin vojaška družina povezuje z nekdanjimi sovjetskimi častniškimi družinami, na Švedskem tega termina ne poznajo in ne uporabljajo. Pa v Sloveniji?

Zakon o službi v Slovenski vojski, sprejet leta 2007, ki je pomembno prispeval k uzakonitvi celostne podpore za pripadnike in pripadnice Slovenske vojske, je vojaške družine definiral posredno, z naštevanjem, kdo vse je upravičen do celostne skrbi poleg pripadnika SV.

Naše dosedanje raziskovanje kaže, da se vojaška družina razume kot družina, v kateri je vsaj en družinski član zaposlen v Slovenski vojski. Pri tem govorimo o različnih oblikah vojaških družin, lahko gre za starša ali za otroka zaposlenega v SV, lahko gre za jedrno ali večgeneracijsko družino, za družino, v kateri sta oba starša zaposlena v SV, ali družino, v kateri je vojaške škornje obul oče ali mati. Vojaška družina je več kot zakonsko definirana jedrna družina pripadnika ali pripadnice SV. Gre za vprašanje identitete in vojaške kulture, ki se prenaša (ali pa ne) na ožjo oziroma širšo družino. Kot se na družino prenašajo tudi izzivi in težave, s katerimi se spoprijemajo pripadniki in pripadnice SV ter lahko vodijo v psihične, čustvene in fizične zdravstvene težave ter slabe medosebne partnerske odnose ter odnose med starši in otroki. Različni dejavniki tveganja so prisotni tudi v širši družbi, ne le v vojski, a vojaški poklic je še posebno zahteven.

Morda se po mnenju dela civilne družbe $\mathrm{s}$ tveganjem spoprijemajo ljudje $\mathrm{v}$ številnih poklicih, v katerih morajo starši velikokrat na službeno pot in tudi delovne nadobremenitve niso v današnjem času nič posebnega. Posebnost vojaškega poklica pa je, da tu starši niso na službeni poti le nekaj dni, temveč so odsotni več mesecev, pri čemer gre lahko celo za ponavljajoče se odsotnosti. Naloge, ki jih morajo v času odsotnosti opravljati vojaški starši, niso vsakodnevne rutinske obveznosti, temveč so pogosto povezane s povečano stopnjo ogroženosti in tudi možnostjo poškodbe ali celo smrti. Nič nenavadnega ni, če so starši odsotni v času rojstva otroka in morda ga prvič vidijo, ko ni več novorojenček. Delovna nadobremenitev se ne meri v dveh urah dela čez delovni čas, temveč v dveh tednih na terenu, v blatu, mrazu, vetru, vročini in drugih neugodnih razmerah. Tveganje pri delu pa ni definirano kot možnost nesreče pri delu, temveč zavestna odločitev posameznika ali posameznice, ki je pripravljen izgubiti življenje pri opravljanju nalog za doseganje ciljev naše skupne države. Na tem mestu bi težko rekli, da vse našteto vpliva le na pripadnika ali pripadnico SV. Vse našteto pomembno vpliva na celotno družino. Odpovedovanje, usklajevanje, stres, strah pred izgubo družinskega člana in paleta čustev so prisotni v celotni vojaški družini, od otrok in partnerjev do starih staršev.

V času pisanja teh vrstic se pripadniki in pripadnice SV spoprijemajo z novim izzivom, saj predstavljajo enega od najpomembnejših elementov spopada $\mathrm{z}$ epidemijo zaradi virusa SARS-CoV-2. Pri projektu Vojaško specifični dejavniki tveganja za dobrobit in zdravje vojaških družin smo aprila 2020 izvedli presečno študijo, v kateri smo ugotavljali, kako so vojaške družine prilagodile svoje vsakdanje življenje tem izjemno 
nevsakdanjim okoliščinam. Če izhajamo iz mnenj respondentov, lahko sklepamo, da so vojaške družine precej odporne in prilagodljive. Niso pa neuničljive in včasih bi bile vesele podpore, pa naj pride od prijateljev, sodelavcev ali pa v obliki formalne podpore SV ali državnih ukrepov. Še posebno so ranljive družine s predšolskimi in mlajšimi šoloobveznimi otroki, za katere so bili ukrepi v času epidemije najmanj ustrezni. V času karantene in družbene samoizolacije, ob odsotnosti vrtcev, šol in brez podpore starih staršev lahko vojaške aktivnosti, na primer večdnevne odsotnosti in vojaške vaje, za družino pomenijo težko obvladljiv izziv, ki lahko vodi tudi v zdravstvene težave.

Zadovoljne in zdrave vojaške družine so gotovo dobra podlaga za uspešno in predano delo pripadnikov in pripadnic, najverjetneje pa tudi pomemben dejavnik pri odločanju za nadaljevanje poklicne poti v Slovenski vojski.

Nikar ne zamerite, če vas ob koncu naslovim neposredno, pripadniki in pripadnice Slovenske vojske. V službi domovine niste le vi, temveč velikokrat tudi vaše družine, ki vas čustveno, logistično, organizacijsko in še kako drugače podpirajo, se v vsakdanjem življenju prilagajajo vašim delovnim zahtevam, vašemu vojaškemu poslanstvu podrejajo svojo kariero, vam ne očitajo, ko ste v mednarodnih operacijah in na misijah ravno takrat, ko vaš otrok praznuje rojstni dan ali potrebuje tolažbo, ker je umrl hišni ljubljenček. Vedno znova pokončno, čeprav včasih z grenkobo, sprejemajo vaše odhode in prihode, saj se zavedajo, da je vojak mirnejši, uspešnejši, samozavestnejši pri opravljanju nalog in posledično varnejši, če ve, da ga doma podpira družina, nevidni steber vojaškega poklica. 
